\title{
Activity and Selectivity for O-2 Reduction to H2O2 on Transition Metal Surfaces
}

Siahrostami, Samira; Verdaguer Casadevall, Arnau; Karamad, Mohammadreza; Chorkendorff, Ib; Stephens, Ifan; Rossmeisl, Jan

\section{Published in:}

E C S Transactions

Link to article, DOI:

10.1149/05802.0053ecst

Publication date:

2013

Document Version

Publisher's PDF, also known as Version of record

Link back to DTU Orbit

Citation (APA):

Siahrostami, S., Verdaguer Casadevall, A., Karamad, M., Chorkendorff, I., Stephens, I., \& Rossmeisl, J. (2013). Activity and Selectivity for O-2 Reduction to H2O2 on Transition Metal Surfaces. E C S Transactions, 58(2), 5362. https://doi.org/10.1149/05802.0053ecst

\section{General rights}

Copyright and moral rights for the publications made accessible in the public portal are retained by the authors and/or other copyright owners and it is a condition of accessing publications that users recognise and abide by the legal requirements associated with these rights.

- Users may download and print one copy of any publication from the public portal for the purpose of private study or research.

- You may not further distribute the material or use it for any profit-making activity or commercial gain

- You may freely distribute the URL identifying the publication in the public portal 


\title{
Activity and Selectivity for $\mathrm{O}_{2}$ Reduction to $\mathrm{H}_{2} \mathrm{O}_{2}$ on Transition Metal Surfaces
}

\author{
Samira Siahrostami ${ }^{\mathrm{a}}$, Arnau Verdaguer-Casdevall ${ }^{\mathrm{b}}$, Mohammadreza Karamad, \\ Ib Chorkendorff ${ }^{\mathrm{b}}$, Ifan Stephens, ${ }^{\mathrm{b}}$ Jan Rossmeisl ${ }^{\mathrm{a}}$ \\ ${ }^{a}$ Center for Atomic Scale Materials Design, Department of Physics, Technical University \\ of Denmark, Fysikvej, Kongens Lyngby, Denmark 2800 \\ ${ }^{\mathrm{b}}$ Center for Individual Nanoparticle Functionality, Technical University of Denmark, \\ Fysikvej, Kongens Lyngby, Denmark 2800
}

Industrially viable electrochemical production of $\mathrm{H}_{2} \mathrm{O}_{2}$ requires active, selective and stable electrocatalyst materials to catalyse the oxygen reduction reaction to $\mathrm{H}_{2} \mathrm{O}_{2}$. On the basis of density functional theory calculations, we explain why single site catalysts such as $\mathrm{Pd} / \mathrm{Au}$ show improved selectivity over pure metals such as $\mathrm{Au}$.

\section{Introduction}

Hydrogen peroxide is ranked by Myers as one of the most important 100 chemicals in the world.(1) Its total production exceeds $3 \mathrm{M}$ tons per annum.(2) It is mainly used as a "green" oxidising agent, particularly for waste water treatment and in the paper industry. There is an increasing interest in the use of $\mathrm{H}_{2} \mathrm{O}_{2}$ in fuel cells, both as an oxidant and as a fuel.(3) Since it is a liquid, it is much more convenient to transport and store than gas phase reactants such as $\mathrm{H}_{2}$ or $\mathrm{O}_{2}$.

At present, $\mathrm{H}_{2} \mathrm{O}_{2}$ is produced via the anthraquinone process from hydrogen and oxygen. This is a batch process, involving the sequential hydrogenation and oxidation of hydroquinone molecules in an organic solvent.(2) In principle, the production of $\mathrm{H}_{2} \mathrm{O}_{2}$ should actually release energy; given its negative Gibbs Free Energy of formation, $\Delta G_{f}=$ $-120 \mathrm{~kJ} \mathrm{~mol}^{-1}$. However, in practice, the anthraquinone process actually consumes $150 \mathrm{~kJ}$ $\mathrm{mol}^{-1}$, mainly to cool down the reactors.(4) The complexity of the anthraquinone process means that it is only feasible to conduct it in on a very large scale, with each plant typically yielding 50 ktons per annum.(2) This also means that the $\mathrm{H}_{2} \mathrm{O}_{2}$ needs to be transported from the centralised production plants, causing logistical challenges.

Over the past decade, the heterogeneous catalysis community has devoted a large body of research towards the development of an alternative to the anthraquinone process. The "direct catalytic" route is a simpler, continuous process, whereby $\mathrm{O}_{2}$ is reduced directly by $\mathrm{H}_{2}$ on solid catalysts.(5-9) It lends itself better to small scale production, so that $\mathrm{H}_{2} \mathrm{O}_{2}$ could be produced close to the point of consumption. The most active and selective catalysts for this process are based on Pd modified Au nanoparticles, denoted as Pd-Au. $(6,8,9)$ Despite the relative simplicity of this method in comparison to the anthraquinone process, it would be preferable to avoid the explosive mixture of $\mathrm{H}_{2}$ and $\mathrm{O}_{2}$ altogether. 
In comparison to the anthraquinone and the direct catalytic processes, the electrochemical reduction of $\mathrm{O}_{2}$ to $\mathrm{H}_{2} \mathrm{O}_{2}$, i.e. $\mathrm{O}_{2}+2 \mathrm{H}^{+}+2 \mathrm{e}^{-}=\mathrm{H}_{2} \mathrm{O}_{2}$, seems to be an attractive option. When produced at the cathode of a fuel cell, with hydrogen oxidation at the anode, it should, in principle, be possible to release the $\Delta G_{f}=-120 \mathrm{~kJ} \mathrm{~mol}^{-1}$ as electrical energy. Should one wish to avoid the use of $\mathrm{H}_{2}, \mathrm{H}_{2} \mathrm{O}_{2}$ could also be produced in an electrolyser, in which case $\sim 200 \mathrm{~kJ} \mathrm{~mol}^{-1}$ input would be required (assuming $1 \mathrm{~V}$ potential difference). Despite the obvious appeal of the electrochemical production of $\mathrm{H}_{2} \mathrm{O}_{2}$, it has largely been overlooked by the electrochemistry community.

Nonetheless, the viability of the electrochemical production of $\mathrm{H}_{2} \mathrm{O}_{2}$ depends on further improvements to the electrocatalysts at its cathode. Not only does the catalyst needs to be active, but also selective, i.e. favoring the 2-electron reduction of $\mathrm{O}_{2}$ to $\mathrm{H}_{2} \mathrm{O}_{2}$ over the thermodynamically favored 4-electron pathway to $\mathrm{H}_{2} \mathrm{O}$, i.e. $\mathrm{O}_{2}+4 \mathrm{H}^{+}+4 \mathrm{e}^{-}=\mathrm{H}_{2} \mathrm{O}$.

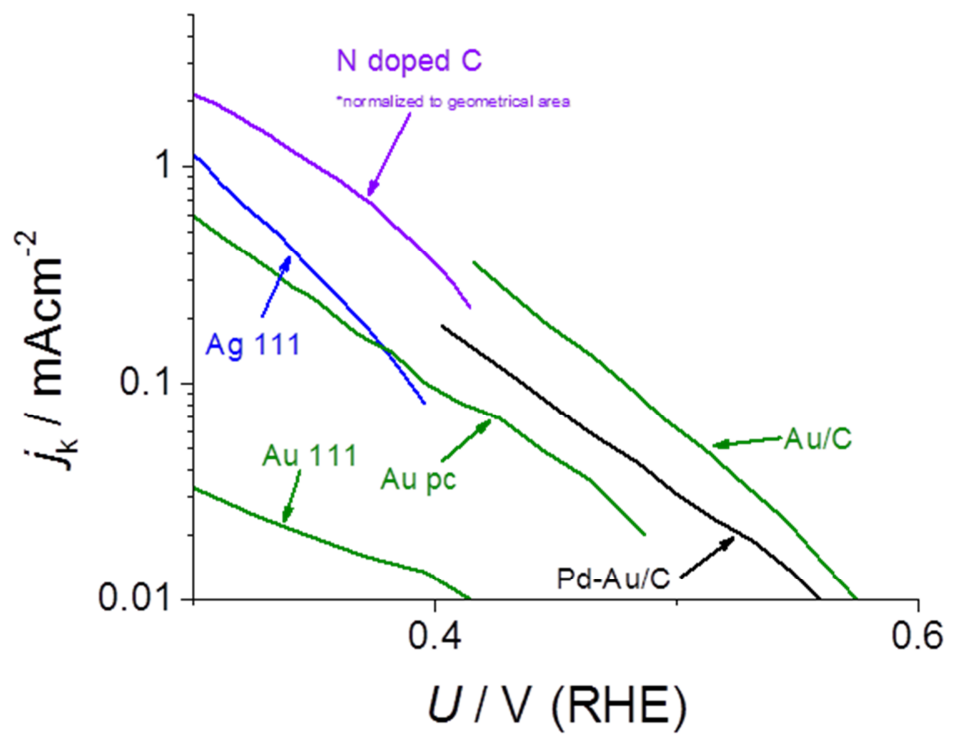

Figure 1. Polarisation plots showing $\mathrm{H}_{2} \mathrm{O}_{2}$ production current, $j_{\mathrm{k}}$ as a function of potential, $U$, for a number of different catalysts, derived from the ring current and corrected for mass transport limitations, in accordance to Paulus et al.(10) The data are collected from a number of different studies: $\mathrm{Au}(111)$ from Alvarez-Rizatti et al;(11) $\mathrm{Au}(\mathrm{pc})$ from Jirkovsky et al;(12) Ag(111) from Blizanac et al;(13) N-doped C from Fellinger et al;(14) $\mathrm{Au} / \mathrm{C}$ and $\mathrm{Pd}-\mathrm{Au} / \mathrm{C}$ from Jirkovsky et al(15). In the case of $\mathrm{Au}(111)$, we assumed $100 \%$ selectivity to $\mathrm{H}_{2} \mathrm{O}_{2}$, meaning that the plotted current provedes an upper limit for the actual activity.

In order to establish the current state-of the-art, the polarisation plots from a number of different studies is plotted on Figure 1. The activity increases roughly in the following order $\mathrm{Au}(111)<\mathrm{Au}(\mathrm{pc})<\mathrm{Ag}(111)<\mathrm{Pd}-\mathrm{Au} / \mathrm{C}<\mathrm{N}$-doped $\mathrm{C}<\mathrm{Au} / \mathrm{C}$. Evidently, some of the Au-based catalysts show reasonable activity.(15) However, it also seems that the activity of $\mathrm{Au}$ towards $\mathrm{O}_{2}$ reduction is highly sensitive to the catalyst structure, with the carbon supported nanoparticles, Au/C being most active.(15) Even so, the selectivity, which is potential dependent, shows a maximum value that is only $80 \%$. Curiously, the catalyst of choice for the direct gas phase catalytic production of $\mathrm{H}_{2} \mathrm{O}_{2}, \mathrm{Pd}-\mathrm{Au} / \mathrm{C}$ also 
shows similar activity to $\mathrm{Au} / \mathrm{C}$. However, it shows much greater selectivity than $\mathrm{Au} / \mathrm{C}$, at $\sim 90 \%$.(15)

It is also striking that $\mathrm{N}$-doped carbon shows an apparent activity almost as high as $\mathrm{Au} / \mathrm{C}$. However, it should be borne in mind that the metal free $\mathrm{N}$-doped $\mathrm{C}$ is a highly porous surface, suggesting that its specific activity is somewhat lower.(14) Moreover, its onset potential is more negative than the other catalysts; this suggests that it would not be possible to increase the current densities at low overpotential by increasing the surface area.

Despite the reasonable activity achieved thus far, it would be preferable if higher current densities were possible at lower overpotentials. Herein, in the current study, we use a density functional theory (DFT) based framework to understand the trends in activity and selectivity of metallic catalysts for the electrochemical production of $\mathrm{H}_{2} \mathrm{O}_{2}$. .

We note that cobalt porphyrin-based catalysts also show high activity for $\mathrm{H}_{2} \mathrm{O}_{2}$ production.(16) However, they are not particularly stable under reaction conditions, as the $\mathrm{N}$-ligands surrounding the active site tend to degrade in the presence of $\mathrm{H}_{2} \mathrm{O}_{2} \cdot(17,18)$ Consequently, we focus our attention on catalysts based on noble metals, which should be sufficiently stable under reaction conditions.

\section{Computational Methods}

The total energies of different adsorbates on each surface were calculated with Density Functional Theory (DFT) using grid-based projector-augmented wave method (GPAW) code.(19) The calculations were performed using RPBE as exchangecorrelation functional.(20) The lattice constants of all alloys were optimized for their respective crystal structures. Periodic model slabs were constructed for all structures considered in this study. .

The $\mathrm{Pd} / \mathrm{Au}(111)$ alloy, $\mathrm{Au}(111)$ and $\mathrm{Ag}(111)$ surfaces were constructed to face center cubic (FCC) structures with closed packed (111) surfaces. For the Pd/Au(111), the lattice constants were assumed to be the same as that of $\mathrm{Au}$. The surfaces were modeled using a four-layer $(\sqrt{3} \times \sqrt{3}) \llbracket R 30 \rrbracket{ }^{\circ}$ slab corresponding to Pd coverage of 1/3 ML. Very similar adsorption energies were obtained with lower coverage of Pd atoms, suggesting that they are largely independent of coverage. The lower two layers were fixed to their bulk structure while the upper layers and adsorbates were allowed to relax. The $\mathrm{Au}(211)$ surface was modeled by $(2 \times 2)$ slab with four closed packed layers, where only the topmost layer and adsorbates were allowed to relax.

Adsorption was only allowed on one side of the slabs. Brillouin zones were sampled using $6 \times 6 \times 1$ and $(4 \times 4 \times 1)$ Monkhorst-Pack k-points for the $\mathrm{Pd} / \mathrm{Au}(111)$, and $\mathrm{Au}(211)$ surfaces, respectively. All structures were allowed to relax in all directions until residual forces were less than $0.05 \mathrm{eV} / \mathrm{A}$. Moreover, in all cases, convergence of total energy with respect to grid spacing and k-point set were considered.

All adsorption sites (atop, bridge and hollow) were considered and only the most stable ones are used here. All free energies are calculated relative to $\mathrm{H}_{2} \mathrm{O}(\mathrm{l})$ and $\mathrm{H}_{2}(\mathrm{~g})$. 
Zero point energies and entropies were included in energetics calculations.(21) No corrections were applied to the adsorption energies as a result of solvation, as we assume that water stabilizes $\mathrm{HO}^{*}$ and $\mathrm{HOO}^{*}$ similarly on all alloys.

The adsorption energies for $\operatorname{Pt}(111)$ and $\operatorname{Pd}(111)$ were based on the data from Nørskov et al(21) and Rossmeisl et al.(22)

We have used the computational hydrogen electrode approach to calculate the free energy levels of all intermediate states as a function of potential.(21)

\section{Results and Discussion}

In accordance to a previously published set of DFT calculations, the initial charge transfer step in the oxygen reduction reaction is (where * denotes a vacant active site and $\mathrm{HOO}^{*}$ denotes an adsorbed HOO* intermediate):(21-23)

$$
\mathrm{O}_{2}+\mathrm{H}^{+}+\mathrm{e}^{-}+* \rightarrow \mathrm{HOO}^{*}
$$

Should $\mathrm{H}_{2} \mathrm{O}_{2}$ be produced via the so-called two electron pathway, the reaction will be completed via the following step:(23)

$$
\mathrm{HOO}^{*}+\mathrm{H}^{+}+\mathrm{e}^{-} \rightarrow \mathrm{H}_{2} \mathrm{O}_{2}+*
$$

Evidently both reaction steps only involve one intermediate, HOO*. The effect of changing the catalyst material is to change the binding of this intermediate, $\Delta G_{\mathrm{HOO}}$. It turns out that on any given surface, the binding energy of HOO* is offset by a constant $3.2 \pm 0.2 \mathrm{eV}$ from that of $\mathrm{HO}^{*}, \Delta G_{\mathrm{HO}} *(24,25)$ Consequently, both $\Delta G_{\mathrm{HO} *}$ and $\Delta G_{\mathrm{HOO}} *$ can be used as a "descriptor" to describe the trends in activity for $\mathrm{H}_{2} \mathrm{O}_{2}$ production. (23) This is demonstrated on Fig 2a, where the thermodynamic limiting potential for $\mathrm{H}_{2} \mathrm{O}_{2}$ production, $U_{T}$, is plotted, in blue, as a function of $\Delta G_{\mathrm{HO}}$; the $\mathrm{HOO}^{*}$ binding energy is also displayed on the upper horizontal axis for comparison. The thermodynamic overpotential for the 2-electron reaction, $\eta_{\mathrm{O}_{2} / \mathrm{H}_{2} \mathrm{O}_{2}}$, is the distance from the Nernstian potential for $\mathrm{H}_{2} \mathrm{O}_{2}$ production, $U_{\mathrm{O}_{2} / \mathrm{H}_{2} \mathrm{O}_{2}}^{0}=0.7 \mathrm{~V}$, to the $U_{\mathrm{T}}$. At the $U_{\mathrm{T}}$, the catalyst can sustain appreciable kinetic rates for $\mathrm{H}_{2} \mathrm{O}_{2}$ production, due to low charge transfer barriers. (25-27) 


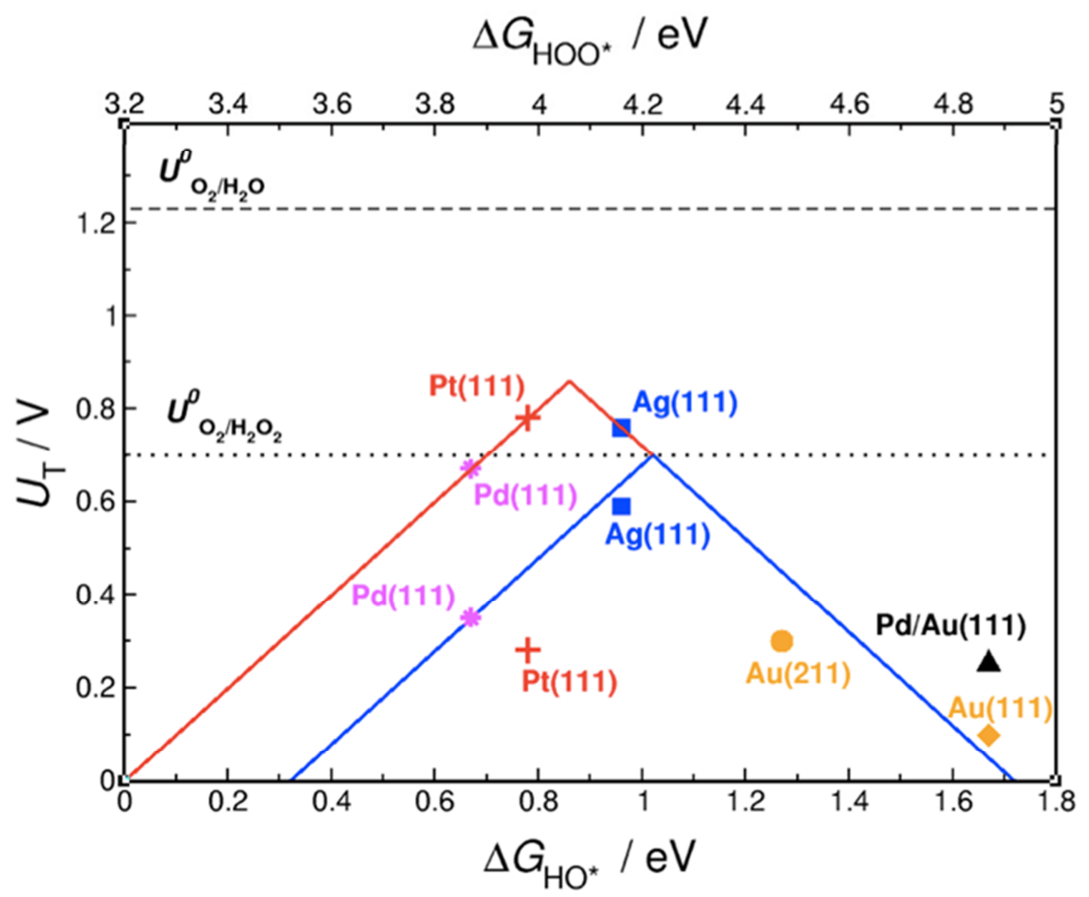

Figure 2. 2-electron (blue) and 4-electron (red) theoretical volcano plot for reduction of $\mathrm{O}_{2}$, with the limiting potential plotted as a function of $\Delta G_{\mathrm{HO}} *($ lower horizontal axis) and $\Delta G_{\mathrm{HOO}}$ (upper horizontal axis). In the case of $\operatorname{Ag}(111), \operatorname{Pt}(111)$ and $\operatorname{Pd}(111)$, both the overpotential for the 4 electron pathway (upper points) and the 2 electron pathway are plotted (lower points).

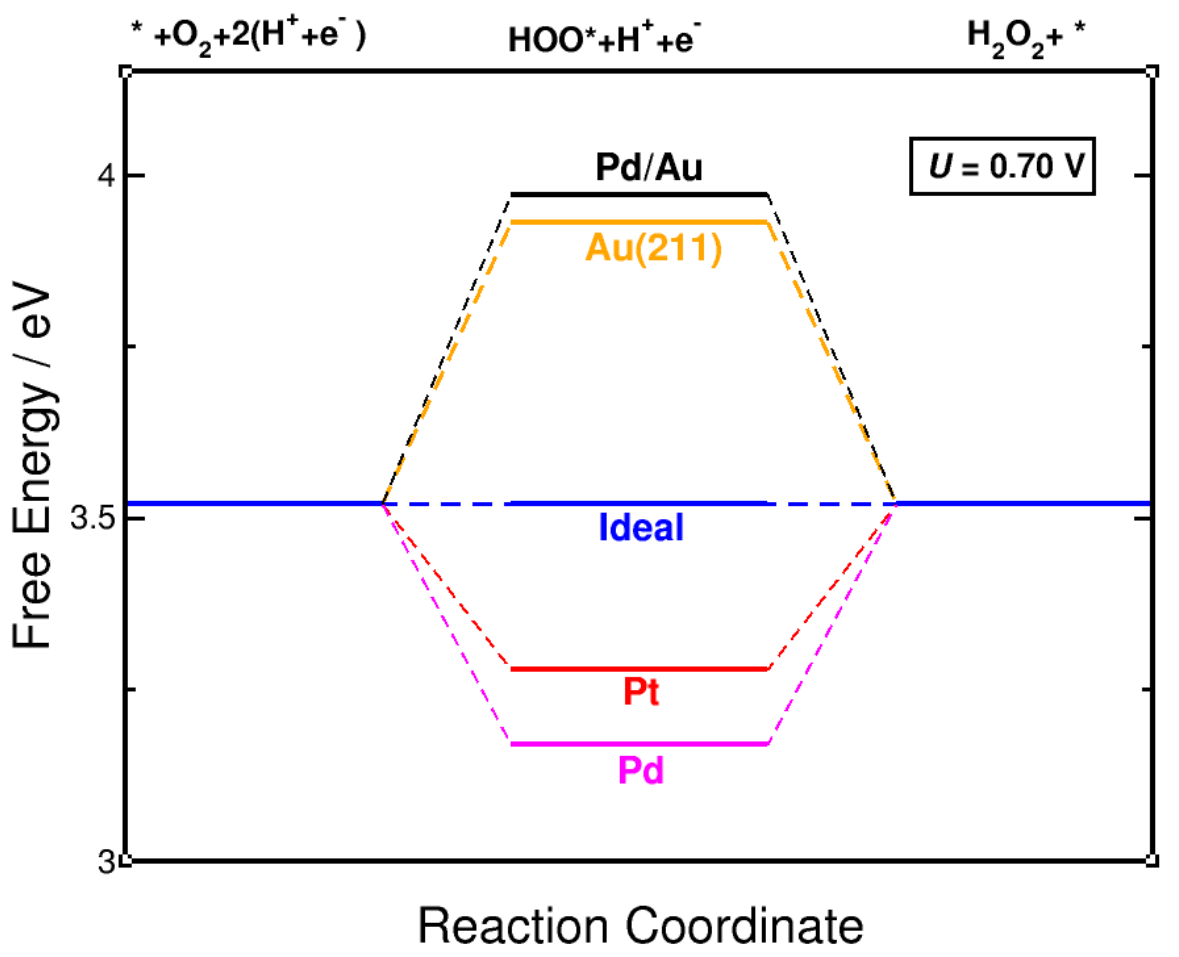

Figure 3. Free energy diagram for a number of different catalysts for $\mathrm{H}_{2} \mathrm{O}_{2}$ production from $\mathrm{O}_{2}$, at the equilibrium potential. 
Evidently, Fig. 2 shows that there is a volcano-type relationship between $\eta_{\mathrm{O}_{2} / \mathrm{H}_{2} \mathrm{O}_{2}}$ (and hence the catalytic activity), and $\Delta G_{\mathrm{HO}}$. On the right hand side of the volcano, the overpotential is due to HOO* formation. For instance, the free energy diagram on Fig $2 b$ shows that on $\mathrm{Au}(211)$, the active site of $\mathrm{Au}$ nanoparticles,(28) it is $0.41 \mathrm{eV}$ uphill to form $\mathrm{HOO}^{*}$ at the equilibrium potential, $0.7 \mathrm{~V}$. Therefore, an equivalent thermodynamic overpotential of $0.41 \mathrm{~V}$ is required to drive the reaction. The reaction free energy for [1] is slightly more positive on $\mathrm{Pd} / \mathrm{Au}(111)$ than $\mathrm{Au}(211)$; this explains the experimental observation that $\mathrm{Au}$ nanoparticles are slightly more active than $\mathrm{Pd}-\mathrm{Au}$ nanoparticles for $\mathrm{H}_{2} \mathrm{O}_{2}$ production.(15)

Catalysts on the left hand side, such as $\mathrm{Pt}$ or $\mathrm{Pd}$, bind $\mathrm{HOO}^{*}$ too strongly, and the overpotential for the 2-electron pathway is due to the reduction of $\mathrm{HOO}^{*}$ to $\mathrm{H}_{2} \mathrm{O}_{2}$. The most optimal catalyst would have a $\Delta G_{\mathrm{HOO}^{*}} \sim 4.2 \pm 0.2 \mathrm{eV}$ and $\eta_{\mathrm{O}_{2} / \mathrm{H}_{2} \mathrm{O}_{2}}=0$, i.e. at the peak of the volcano its free energy diagram is flat at the equilibrium potential, as shown in Fig 2. This means that the "ideal catalyst" would exhibit high kinetic rates for $\mathrm{H}_{2} \mathrm{O}_{2}$ production with zero potential losses. It is also clear from Fig 2 that it should be possible to obtain catalysts much more active for $\mathrm{H}_{2} \mathrm{O}_{2}$ production than the current state of the art, based on $\mathrm{Au}$ or Pd-Au nanoparticles.

Should the reaction proceed via the 4-electron pathway, instead of [2], HOO* will either dissociate via a chemical step:(26)

$$
\mathrm{HOO}^{*}+* \rightarrow \mathrm{O}^{*}+\mathrm{HO}^{*}
$$

Or otherwise be reduced electrochemically:(22)

$$
\mathrm{HOO}^{*}+\mathrm{H}^{+}+\mathrm{e}-\rightarrow \mathrm{O}^{*}+\mathrm{H}_{2} \mathrm{O}
$$

Followed by the further reduction of $\mathrm{O}^{*}$ and $\mathrm{OH}^{*}$ to produce water: $(22,26)$

$$
\begin{gathered}
\mathrm{O}^{*}+\mathrm{H}^{+}+\mathrm{e}-\rightarrow \mathrm{HO}^{*} \\
\mathrm{HO}^{*}+\mathrm{H}^{+}+\mathrm{e}-\rightarrow \mathrm{H}_{2} \mathrm{O}+*
\end{gathered}
$$

It turns out that on almost all metallic catalysts, the overpotential is either due to [1] or [6]. This is the basis for the 4-electron volcano on Fig 2, plotted in red, as a function of $\Delta G_{\mathrm{HO}} *$ and $\Delta G_{\mathrm{HOO}}$. It is important to note that even on the optimal catalyst, a minimum $\eta_{\mathrm{O}_{2} / \mathrm{H}_{2} \mathrm{O}}$ of $\sim 0.4 \mathrm{~V}$ is required to drive $\mathrm{H}_{2} \mathrm{O}$ formation.(29-34) This contrasts with the 2electron volcano, whose peak coincides with the Nernstian potential for the reaction. The high value of $\eta_{\mathrm{O}_{2} / \mathrm{H}_{2} \mathrm{O}}$ is in order to overcome the large constant difference in adsorption energies between the intermediates, $\mathrm{HO}^{*}$ and $\mathrm{HOO}^{*}$ [Error! Bookmark not defined.]. This large thermodynamic overpotential is characteristic of reactions involving more than two intermediates. $(24,35,36)$

Whether or not a catalyst follows the 4-electron or 2-electron pathway depends on the rate of reactions [3] and [4], relative to [2]. The free energy diagram on Fig 4 plots the reaction free energies for $\mathrm{Pt}(111), \mathrm{Pd} / \mathrm{Au}(111)$ and $\mathrm{Au}(211)$, following the electrochemical pathway described by reaction [1-3] and [4-6]. Although only ground 
states are included in this treatment, earlier studies suggest that additional barriers should scale with the reaction free energies via a Brønsted-Evans-Polanyi relationship. $(26,27)$

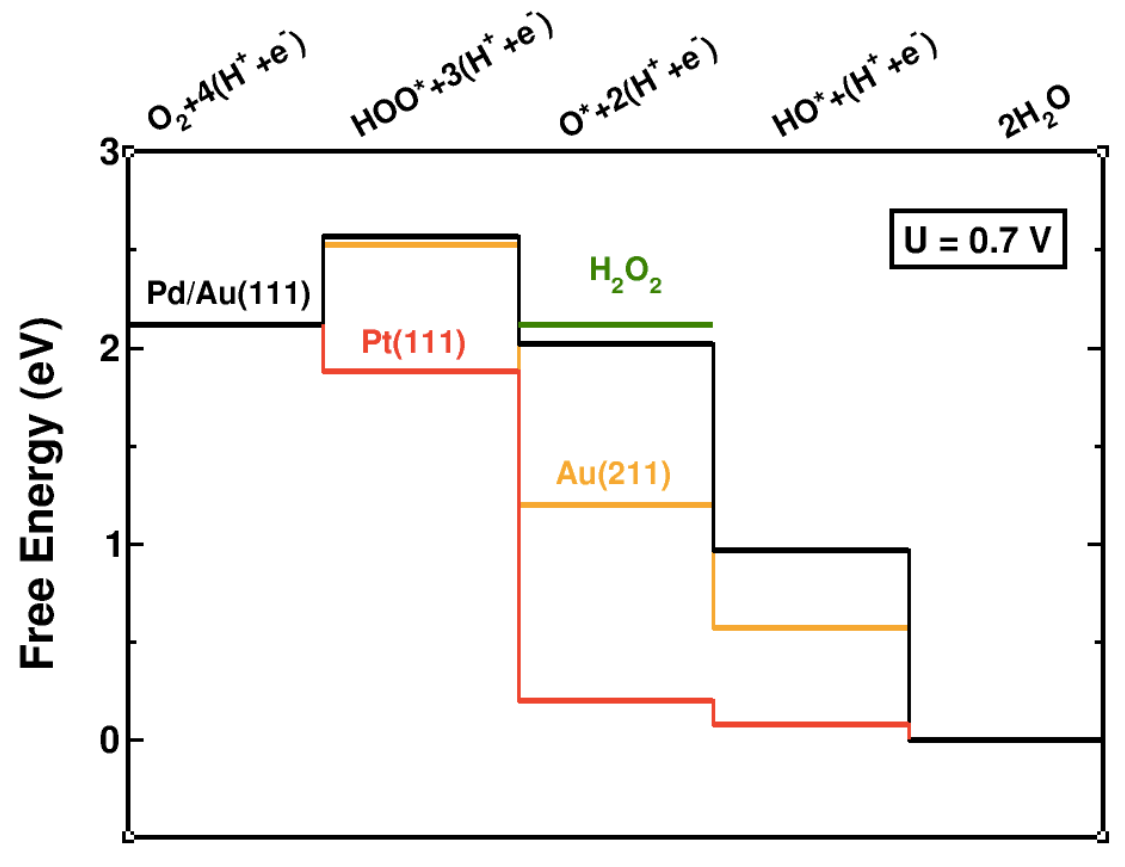

\section{Reaction Coordinate}

Figure 4. Free energy diagram for oxygen reduction at $0.7 \mathrm{~V}$ for $\mathrm{Pd} / \mathrm{Au}(111), \mathrm{Pt}(111)$ and $\mathrm{Au}(211)$. The green line denotes the free energy of $\mathrm{H}_{2} \mathrm{O}_{2}$ in the liquid phase.

On a catalyst such as Pt, which is located on the left hand side of the volcano in Fig 2, $\mathrm{HOO}^{*}, \mathrm{O}^{*}$ and $\mathrm{HO}^{*}$ bind quite strongly to the surface. This means that the 4 electron pathway on these catalysts is determined by the reduction of $\mathrm{HO}^{*}$ to $\mathrm{H}_{2} \mathrm{O}$, i.e. step [6].

Interestingly, Fig 4 also shows that on all three catalysts, at $0.7 \mathrm{~V}$ it is downhill in free energy to reduce $\mathrm{HOO}^{*}$ further to $\mathrm{O}^{*}$ and $\mathrm{HO}^{*}$, whereas the formation of $\mathrm{H}_{2} \mathrm{O}_{2}$ in the liquid phase is thermoneutral. Nonetheless, the free energy diagram can be used to establish the driving force for $\mathrm{HOO}^{*}$ reduction, and hence the selectivity for the reaction. On $\mathrm{Pt}(111)$, it is clearly much more downhill to reduce $\mathrm{HOO}^{*}$ to $\mathrm{O}^{*}$ than on the other two surfaces under consideration.

Although the reaction free energy for $\mathrm{HOO}^{*}$ formation is similar on both $\mathrm{Au}(211)$ and $\mathrm{Pd} / \mathrm{Au}(111)$, it is much more downhill in free energy to form $\mathrm{O}^{*}$ on $\mathrm{Au}(211)$. This explains the experimental observation that $\mathrm{Au}$ nanoparticles, with an abundance of undercoordinated (211) sites, show similar $\mathrm{H}_{2} \mathrm{O}_{2}$ production activity to and $\mathrm{Pd}-\mathrm{Au}$ nanoparticles, but that is the latter are much more selective.

The decreased driving force for $\mathrm{O}^{*}$ formation on $\mathrm{Pd} / \mathrm{Au}(111)$ can be understood on the basis of the geometry of its active site, as depicted in Figure 5. Typically, although $\mathrm{HO}^{*}$ and $\mathrm{HOO}^{*}$ adsorb on the atop site of closely packed surfaces such as $\mathrm{Pt}(111)$ or $\mathrm{Pd}(111), \mathrm{O}^{*}$ adsorbs on the hollow sites. However, on $\mathrm{Pd}-\mathrm{Au}$ nanoparticle the $\mathrm{Pd}$ atoms 
are isolated from each other and surrounded by unreactive Au atoms. This forces $\mathrm{O}^{*}$ to adsorb on the atop site, where adsorption is less favourable. Hence the effect of isolating individual reactive atoms is to destabilise $\mathrm{O}^{*}$, relative to $\mathrm{HOO}^{*}$. Interestingly, our earlier DFT calculations suggest that Co porphyrin catalysts function in a similar manner.(37)

We note, in passing, that in the above discussion we have only considered the electrochemical reduction of $\mathrm{HOO}^{*}$, i.e. step [4], rather than its chemical dissociation, step [3]. Nonetheless, since both pathways involve the same intermediates, $\mathrm{O}^{*}$ and $\mathrm{HO}^{*}$, the same trends would persist in either case. In general, the further a catalyst is situated towards the left of the volcano would imply a greater driving force for the formation of $\mathrm{HO}^{*}$ and $\mathrm{O}^{*}$ from $\mathrm{HOO}^{*}$, and hence $\mathrm{H}_{2} \mathrm{O}$ formation. This means that a high catalyst activity may come at the cost of catalyst selectivity.

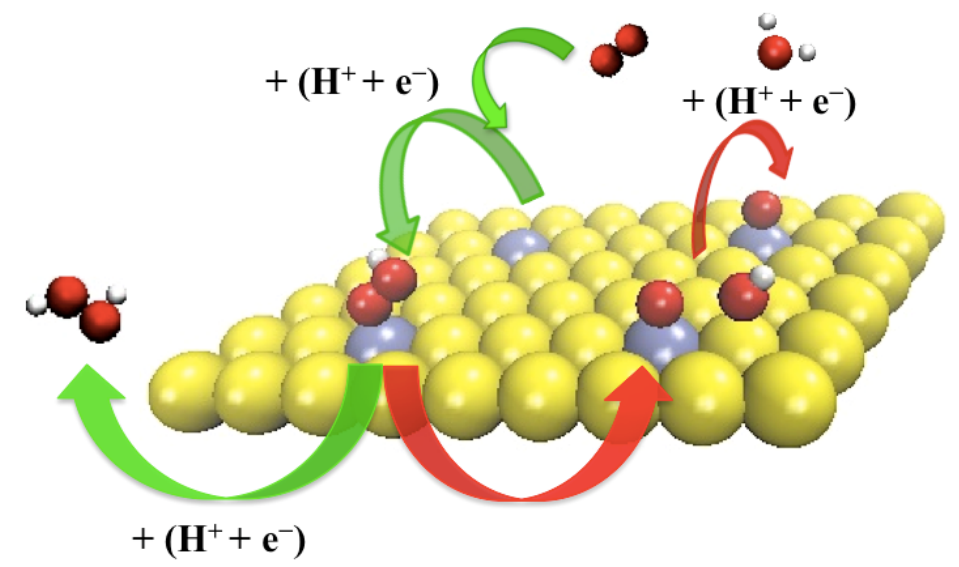

Figure 5. Schematic figure of active site for $\mathrm{Pd} / \mathrm{Au}(111)$ catalyst. $\mathrm{Pd}$ atoms are shown in yellow, Au in grey, $\mathrm{O}$ in red, and $\mathrm{H}$ in white. The 2-electron pathway is demarcated by the green arrows and the 4-electron pathway by the red arrows.

\section{Conclusion}

In this paper we have described a theoretical framework to explain trends in activity and selectivity for $\mathrm{H}_{2} \mathrm{O}_{2}$ production on transition metal surfaces. Using the example of $\mathrm{Pd} / \mathrm{Au}(111)$, we explain why catalysts containing isolated reactive atoms at their active sites show increased selectivity for $\mathrm{H}_{2} \mathrm{O}_{2}$ production, relative to $\mathrm{H}_{2} \mathrm{O}$ production. Future studies will focus on the identification of new catalysts for $\mathrm{H}_{2} \mathrm{O}_{2}$ production, on the basis of this isolated active site concept.

\section{Acknowledgments}

The Center for the Individual Nanoparticle Functionality is funded by the Danish National Research Foundation. The Centre for Atomic-Scale Materials Design is funded by the Lundbeck Foundation. AVC and SS gratefully acknowledge funding from the UNIK program of the Danish Ministry of Science for the Catalysis for Sustainable Energy initiative. MK gratefully acknowledges funding from the Danish Council for Independent Research (under the Danish Agency for Science, Technology and Innovation). 


\section{References}

1. R. Myers, L., The 100 most important chemical compounds: a Reference Guide, Greenwood, Westport, CT, USA (2007).

2. Ullmann's Encyclopedia of Industial Chemistry, Wiley-VCH (2011).

3. S. Fukuzumi, Y. Yamada and K. D. Karlin, Electrochimica Acta, 82, 493 (2012).

4. D. Hancu, H. Green and E. J. Beckman, Ind. Eng. Chem. Res., 41, 4466 (2002).

5. J. M. Campos-Martin, G. Blanco-Brieva and J. L. G. Fierro, Angew. Chem.-Int. Edit., 45, 6962 (2006).

6. J. K. Edwards, B. Solsona, E. N. N, A. F. Carley, A. A. Herzing, C. J. Kiely and G. J. Hutchings, Science, 323, 1037 (2009).

7. D. C. Ford, A. U. Nilekar, Y. Xu and M. Mavrikakis, Surf. Sci., 604, 1565 (2010).

8. L. C. Grabow, B. Hvolbaek, H. Falsig and J. K. Norskov, Top. Catal., 55, 336 (2012).

9. R. B. Rankin and J. Greeley, ACS Catalysis, 2, 2664 (2012).

10. U. A. Paulus, T. J. Schmidt, H. A. Gasteiger and R. J. Behm, J. Electroanal. Chem., 495, 134 (2001).

11. M. Alvarez-Rizatti and K. Juttner, J. Electroanal. Chem., 144, 351 (1983).

12. J. S. Jirkovsky, M. Halasa and D. J. Schiffrin, Physical Chemistry Chemical Physics, 12, 8042 (2010).

13. B. B. Blizanac, P. N. Ross and N. M. Markovic, Electrochimica Acta, 52, 2264 (2007).

14. T. P. Fellinger, F. Hasche, P. Strasser and M. Antonietti, J. Am. Chem. Soc., 134, 4072 (2012).

15. J. S. Jirkovsky, I. Panas, E. Ahlberg, M. Halasa, S. Romani and D. J. Schiffrin, J. Am. Chem. Soc., 133, 19432 (2011).

16. P. Gouerec and M. Savy, Electrochimica Acta, 44, 2653 (1999).

17. C. W. B. Bezerra, L. Zhang, K. C. Lee, H. S. Liu, A. L. B. Marques, E. P. Marques, H. J. Wang and J. J. Zhang, Electrochimica Acta, 53, 4937 (2008).

18. H. Schulenburg, S. Stankov, V. Schunemann, J. Radnik, I. Dorbandt, S. Fiechter, P. Bogdanoff and H. Tributsch, Journal of Physical Chemistry B, 107, 9034 (2003).

19. J. J. Mortensen, L. B. Hansen and K. W. Jacobsen, Physical Review B, 71, 035109 (2005).

20. B. Hammer, L. B. Hansen and J. K. Norskov, Physical Review B, 59, 7413 (1999).

21. J. K. Nørskov, J. Rossmeisl, A. Logadottir, L. Lindqvist, J. R. Kitchin, T. Bligaard and H. Jonsson, Journal of Physical Chemistry B, 108, 17886 (2004).

22. J. Rossmeisl, G. S. Karlberg, T. Jaramillo and J. K. Nørskov, Faraday Discussions, 140, 337 (2008).

23. V. Viswanathan, H. A. Hansen, J. Rossmeisl and J. K. Norskov, J. Phys. Chem. Lett., 3, 2948 (2012). 
24. M. T. M. Koper, J. Electroanal. Chem., 660, 254 (2011).

25. I. E. L. Stephens, A. S. Bondarenko, U. Grønbjerg, J. Rossmeisl and I. Chorkendorff, Energy Environ. Sci., 5, 6744 (2012).

26. V. Tripkovic, E. Skúlason, S. Siahrostami, J. K. Nørskov and J. Rossmeisl, Electrochimica Acta, 55, 7975 (2010).

27. M. J. Janik, C. D. Taylor and M. Neurock, J. Electrochem. Soc., 156, B126 (2009).

28. G. A. Tritsaris, J. Greeley, J. Rossmeisl and J. K. Nørskov, Catal. Lett., 141, 909 (2011).

29. V. R. Stamenkovic, B. Fowler, B. S. Mun, G. F. Wang, P. N. Ross, C. A. Lucas and N. M. Markovic, Science, 315, 493 (2007).

30. J. Greeley, I. E. L. Stephens, A. S. Bondarenko, T. P. Johansson, H. A. Hansen, T. F. Jaramillo, J. Rossmeisl, I. Chorkendorff and J. K. Nørskov, Nature Chemistry, 1, $552(2009)$.

31. J. Suntivich, H. A. Gasteiger, N. Yabuuchi, H. Nakanishi, J. B. Goodenough and Y. Shao-Horn, Nature Chemistry, 3, 546 (2011).

32. J. Suntivich, K. J. May, H. A. Gasteiger, J. B. Goodenough and Y. Shao-Horn, Science, 334, 1383 (2011).

33. I. C. Man, H.-Y. Su, F. Calle-Vallejo, H. A. Hansen, J. I. Martínez, N. G. Inoglu, J. Kitchin, T. F. Jaramillo, J. K. Nørskov and J. Rossmeisl, ChemCatChem, 3, 1159 (2011).

34. M. Escudero-Escribano, A. Verdaguer-Casadevall, P. Malacrida, U. Grønbjerg, B. P. Knudsen, A. K. Jepsen, J. Rossmeisl, I. E. L. Stephens and I. Chorkendorff, J. Am. Chem. Soc., 134, 16476 (2012).

35. A. A. Peterson and J. K. Norskov, J. Phys. Chem. Lett., 3, 251 (2012).

36. J. Rossmeisl, Z. W. Qu, H. Zhu, G. J. Kroes and J. K. Nørskov, J. Electroanal. Chem., 607, 83 (2007).

37. S. Siahrostami, M. E. Bjorketun, P. Strasser, J. Greeley and J. Rossmeisl, Physical Chemistry Chemical Physics, 15, 9326 (2013). 